Espacio, Tiempo y Forma, Serie VII, $H^{a}{ }^{a}$ del Arte, $t .16,2003$, págs. 11-28

\title{
Fartan sus iras en forma semblante: La tumba de Álvaro de Luna y el status de la imagen en la Castilla tardomedieval *
}

\author{
Rosa M. a Rodríguez PoRTo \\ Grupo de Investigación. Universidad de Santiago de Compostela
}

\begin{abstract}
RESUMEN
La tumba erigida por Álvaro de Luna en su capilla de la Catedral de Toledo fue destruída ya en vida del Maestre. La trascendencia del personaje efigiado, las especiales características del monumento y su violenta desaparición, influyeron en la

gestación, a partir del siglo xvII, de toda una tradición legendaria que ha condicionado hasta hoy el estudio de la tumba. El análisis riguroso de las fuentes textuales permite reconstruir el aspecto originario del sepulcro y el impacto que causó en sus contemporáneos.
\end{abstract}

\begin{abstract}
The particular circumstances that surrounded both the erection and the destruction of Álvaro de Luna's tomb, when he was still alive, generated $a$ legendary history about it. However, the analysis of the written sources allows us to consider again the questions related to its original disposition and reception.
\end{abstract}

\begin{abstract}
«El simulacro alzó los soñolientos párpados y vio formas y colores que no entendió, perdidos en rumores y ensayó temerosos movimientos". JORGE LUIS BORGES, EI Golem.
\end{abstract}

* Este artículo tiene como origen un Trabajo Académico Dirigido por la Profa. Rocío Sánchez Ameijeiras en el año 2001 con el título El arte en tiempos de Juan II de Castilla. Sin sus consejos, sugerencias y aliento no habría podido finalizarlo. Sirva esto de pequeña muestra de mi admiración y cariño. También quiero hacer constar mi agradecimiento al prof. Felipe Pereda, quien amablemente me permitió consultar su artículo «Entre Portugal y Castilla: la secuencia formal de las capillas ochavadas de cabecera en el siglo $x v »$ (en prensa). 
La asombrosa proliferación de capillas funerarias privadas, cada vez más ostentosas, es un fenómeno característico de la Baja Edad Media, al que los historiadores del arte y de las mentalidades han prestado especial atención. CastiIla participa de esta tendencia, y como en otros contextos, los conjuntos sepulcrales se convierten en elementos parlantes ideados para la exaltación del individuo y su linaje ${ }^{1}$. En ellos, «la insolencia [de la nobleza] se alía al poder y a un cierto refinamiento cultural, no exento en ocasiones de sensibilidad estética", como afirma Yarza ${ }^{2}$. En concreto, el ambiente literario y caballeresco de la corte de Juan II favoreció la construcción de las más bizarras fantasías, como si los nobles levantiscos hubieran trasladado su rivalidad a un nuevo campo de batalla: el de la fama póstuma. Algunos ejemplos rozan la extravagancia, como la «magnífica y diferenciada sepultura, a manera de nave, con su mástil y popa», encargada por los Almirantes de Castilla para su panteón en Santa Clara de Palencia ${ }^{3}$. Pero de entre todos ellos, fue el sepulcro que Álvaro de Luna ordenó hacer para su capilla en la en Catedral de Toledo el que ejerció un influjo más poderoso en la imaginación de sus contemporáneos, y más aún en la de generaciones posteriores.

El Condestable habia elegido decorar su monumento con su propia efigie sedente, fundida en bronce o cobre sobredorado, para dejar testimonio de su posición en la sociedad, pues «de treynta e dos años que el gouerno e rigio el reyno, en los veynte dellos non se fizo prouision en lo tenporal nin espiritual si non por su mano e por su consentimiento" " 4 . Lamentablemente, tan fascinante monumento fue destruido por los enemigos políticos de Don Álvaro, ya en vida de éste. Su memoria y la de su esposa hubo de ser rescatada, décadas después de su muerte, por su hija María de Luna quien encargó en 1489 a Sebastián de Toledo los dos sepulcros de mármol que todavía pueden verse en la catedral primada ${ }^{5}$. Ya desde

\footnotetext{
1 YARZA LUACES, J.: "La capilla funeraria hispana en torno a 1400" en La idea y el sentimiento de la muerte en la Historia y en el Arte de la Edad Media (coord. por E. PORTELA y M. NúNÉz RodRíguez), Santiago, 1988, págs. 67-91. Véase también NúÑEZ RodríGUEZ, M.: La idea de inmortalidad en la escultura gallega, Ourense, Diputación Provincial, 1985.

2 YARZA LUACES, J.: "La imagen del rey y la imagen del noble en el siglo XV castellano" en Realidad $e$ imágenes de poder. España a fines de la Edad Media (coord. por A. Rucquoi), Valladolid, 1988, pág. 280.

${ }_{3}$ Testimonio del arcediano del Alcor (1539), recogido por FERNÁNDEZ DE MADRID, A.: Silva palentina, I, Palencia, 1932. Citado a su vez en CASTRO, M. de: El Real Monasterio de Santa Clara de Palencia y los Enriquez, Almirantes de Castilla, Palencia, 1982, pág. 56.

4 Fernán PÉrez de Guzmán, Generaciones y semblanzas (ed. de J. Domínguez Bordona), Madrid, Austral, 1965, [1924], págs. 134-135.

5 Sobre los sepulcros que hoy contemplamos, véanse AzcáRATE, J. M. de: «El maestro Sebastián de Toledo y el doncel de Sigüenza», Wad-al-hayara, I, 1974, págs. 7-34; CARRETE PARRONDO, J.: «Sebastián de Toledo y el sepulcro de Álvaro de Luna", Revista de Ideas Estéticas, 131, t. XXXIII, 1975, págs. 231237; Yarza Luaces, J.: Los Reyes Católicos, Madrid, Electa, 1993, págs. 240-243, y Lenaghan, P.: "Conmemorating a real bastard: the chapel of Álvaro de Luna" en Memory and the Medieval Tomb (coord. por E. Valdez del Álamo y C. Stamatis Pendercast), Hampshire, Ashgate, 2000, págs. 128-145.
} 
Fartan sus iras en forma semblante: La tumba de Álvaro de Luna y el status...

el siglo Xv, tanto el primitivo sepulcro del Condestable como su violenta desaparición alimentaron todo tipo de leyendas. Por ello, el propósito del presente artículo es doble: en primer lugar intentaré reconstruír la apariencia original del monumento que don Álvaro encargó para sí, desembarazando de ornamentos legendarios su estructura y, en segundo lugar, trataré de precisar la relación que se debió establecer entre este sepulcro y su audiencia potencial. Intentando mantener una línea argumental coherente, dedicaré una parte de este trabajo al estudio de las fuentes textuales relacionadas con la tumba, para después profundizar en el análisis y contextualización de la obra. Como veremos, sus peculiaridades tipológicas, los materiales empleados y, sobre todo, su destrucción y consiguiente fortuna literaria, lo sitúan en un lugar especial dentro del panorama escultórico castellano. Éstas y otras razones lo convierten en un ejemplo especialmente sugerente para debatir cuestiones de fondo sobre la función de la imagen y su status en el tardomedievo.

\section{EL SEPULCRO DE ÁLVARO DE LUNA A TRAVÉS DE LAS FUENTES LITERARIAS Y DOCUMENTALES}

En 1453 el ambicioso Maestre de Santiago fue ajusticiado públicamente en Valladolid, convirtiéndose en exemplum de la inconstancia de las honras vanas y caducas de este mundo ${ }^{6}$. Así lo retrataron dos de sus enemigos declarados, el Marqués de Santillana en su Doctrinal de Privados y Jorge Manrique en sus celebérrimas Coplas a la muerte de su padre. Este mismo tópico literario, el de los vaivenes de la Fortuna, había sido desarrollado en extenso, todavía en vida del Condestable, por Juan de Mena en su Laberinto de Fortuna (o las CCC). Precisamente, es en esta compleja obra alegórica en la que la caprichosa Fortuna gobierna la rueda del tiempo presente ${ }^{7}$, donde encontramos la más antigua descripción del sepulcro de Don Álvaro, junto a una críptica alusión a su destrucción. El poeta cordobés, un cortesano que conoció directamente a los personajes implicados en los hechos, inmortalizó la misteriosa tumba en la copla CCLXV:

"Ca un condestable armado, que sobre un gran vulto de oro estava asentado, con manos sañosas vimos derribado, e todo desfecho fue tornado en cobre. ¿Pues como queredes que otra vez obre

${ }^{6}$ Véase también MARINO, N. F.: «The creation of a contemporary exemplum: Álvaro de Luna», en Nunca fue pena mayor. Estudios de Literatura Española en homenaje a Brian Dutton (coord. por A. MENÉndez Collera y V. Roncero López), Universidad de Castilla-La Mancha, 1996, págs. 489-494.

7 DEYERMOND, A.: «La ideología del Estado moderno en la literatura española del siglo XV», en Realidad e imágenes de poder (coord. por A. RucQuoI), Valladolid, 1988, págs. 178-181. 
Fortuna, tentando lo que es importuno?

Basta que pudo derribar el uno,

que al otro más duro lo falla que robre» ${ }^{8}$.

Los versos de Mena resultan poderosamente evocadores, pero también oscuros y pesados debido a la sobrecarga erudita y retórica, propia del género en el que se encuadra el poema. Para precisar su sentido, es necesario contextualizarlos en la estructura del Laberinto, una obra de carga política y moralizante en la que tienen cabida todos los grupos sociales del reino, así como los personajes más destacados del presente y el pasado castellano. Cada uno de ellos se encuentra en un «orden» o "círculo» gobernado por un planeta. A Don Álvaro le corresponde el de Saturno, en el que aparece retratado como aquel que «cavalga sobre la Fortuna/ e doma su cuello con ásperas riendas" ${ }^{9}$, por lo que generalmente se ha considerado al Laberinto una obra de propaganda dirigida no sólo a su dedicatario, el «muy prepotente don Juan el segundo» ${ }^{10}$, sino al propio Condestable ${ }^{11}$. Mucho más sugerente y enriquecedora resulta la interpretación que Webber hace del papel del Condestable en esta obra, quien subraya, con argumentos convincentes, la ambigüedad de los versos de Mena, en los que puede verse un ataque encubierto a Don Álvaro y su política ${ }^{12}$. En cualquier caso, la descripción de la tumba aparece integrada en un intra-relato, el de la maga de Valladolid, que ocupa las coplas CCXXXVII-CCLVII, en el que se relata la visita de los partidarios de don Álvaro a la hechicera, con la intención de consultarle acerca del futuro de su señor. Muchos estudios se han consagrado al análisis de este fragmento de difícil lectura, construido a imitación de sendos pasajes de la Farsalia de Lucano (I, vv. 522-559, y V, vv. 539-559) ${ }^{13}$. El primer comentarista de Juan de Mena, Hernán Núñez, nos aclara el sentido de este episodio nigromántico en su edición del Laberinto impresa en Sevilla en 1499, afirmando que «en las guerras entre el condestable y los infantes, algunos, cobdiciando saber cuál parte auría la victoria, consultaron esto con vna muger nigromantesa, la cual resucitó vn cuerpo muerto que le dixo cómo el

\footnotetext{
8 Juan de Mena, Laberinto de Fortuna (ed. de J. G. Cummins), Madrid, Cátedra, 1996, pág. 174. Véanse también las ediciones de M. A. LóPEz Priego, Madrid, Planeta, 1989; y M. P.A.M. KerkHOF, Madrid, Castalia, 1995. Salvo que indique lo contrario, las citas se refieren a la edición de Cummins.

${ }^{9}$ Laberinto de Fortuna, copla CCXXXV, ed. cit., pág. 163.

10 Laberinto de Fortuna, copla I, ed. cit., pág. 55.

11 En este sentido se manifiesta Cummins en la introducción a su edición de la obra, pags. 26-30. Del mismo parecer son DeYermond, A.: Op. cit., págs. 179-180, y Bermejo CaBrero, J. L.: «ldeales políticos en Juan de Mena", Revista de Estudios Políticos, CLXXXVIII, 1973, págs. 158-175.

12 Webber, E. J.: «El enigma del Laberinto de Fortuna» en Philologica in Honorem Manuel Alvar, III, Literatura, Madrid, Gredos, 1986, págs. 563-571.

${ }_{13}$ Se trata de la narración sobre la hechicera de Ericto, aunque también hay referencias a otras fuentes clásicas (las Metamorfosis y la Eneida), además de hechicerías conocidas en la época. Asi lo recoge Kerkhof en su edición del Laberinto, pág. 223. La edición de Cummins, ya citada, incluye una completa bibliografía en las págs. 47-51. Véanse también la que se aporta en la edición de Pérez Priego, págs. XV-XVIII.
} 
Fartan sus iras en forma semblante: La tumba de Álvaro de Luna y el status...

condestable auía de ser vencido y a la fin del todo deshecho, y que, oyendo esto, algunos que seguian el partido del condestable le desampararon y se despidieron d'el; pero dize el poeta en fauor del condestable que los que esto hizieron no sopieron entender la respuesta de la maga, porque todo lo que ella ouo dicho que el condestable sería desfecho salió verdad; que vn estatua de cobre sobredorada del condestable, que estaua en su sepulchro en su capilla de la Yglesia mayor de Toledo, fue deshecha por mandado del infante don Enrrique, que entonces tenía la cibdad en contra del rey don Juan;... esto no se hauía de entender por la persona del condestable, de cuya prudencia más se deuía creer que yría siempre su estado en argumento que no en diminución» ${ }^{14}$.

La estrofa de Mena adquiere, gracias al comentario de Hernán Núñez, todo su sentido. La maga responde a aquellos que la recriminan al considerar que ha errado en su predicción. Para ésta, los enemigos de Don Álvaro y con ellos la caprichosa Fortuna, nada pueden hacer contra él, salvo dirigir sus iras contra la imagen del Condestable situada en su mausoleo: «...basta que pudo derribar el uno (estatua)/ que al otro más duro lo falla que robre (Don Álvaro)". Estos reveladores comentarios de Hernán Núñez nos introducen en el ambiente de fantasmagoría y magia que flotaba en las cortes de Juan II y Enrique IV ${ }^{15}$, y nos servirán, en la segunda parte, para encarar la recepción del sepulcro entre aquellos que lo vieron, o que al menos vivieron en un período en el que los hechos relatados no resultaban muy lejanos. Pero lo que nos interesa en este momento es resaltar que las fuentes más fiabies con las que contamos para conocer la apariencia original del monumento, se limitan a indicar que el sepulcro estaba decorado con una imagen sedente de bronce o cobre sobredorado del Condestable armado. El calificativo «armado", puede hacer alusión al arnés blanco completo que debía lucir la efigie, el mismo tipo de defensas que presentan muchos yacentes nobiliarios contemporáneos ${ }^{16}$, y no, como se ha supuesto, al hecho de que la figura blandiese una espada. Ni Juan de Mena ni su comentarista hacen referencia alguna a la condición articulada de la efigie que la literatura posterior le supone. Intentar aclarar cuál pudo haber sido la estructura del monumento a partir de los versos de Juan de Mena es tarea más difícil, al tratarse de una écfrasis, en la que la mera descripción se ve enturbiada por la imaginería ornamental del autor ${ }^{17}$. Algún historiador ha considerado que el "grand vulto de oro" sobre el que se situaría la es-

${ }^{14}$ Citado en la edición de Kerkhof, págs. 223-224.

15 Sobre este tema, véase Round, N.: "Five Magicians, or the Uses of Literacy», Modern Language Review, 64, 1969, págs. 793-805.

${ }^{16}$ Como ilustración, véase SÁNCHEZ AMEIJEIRAS, R.: «El arnés y el armamento del caballero medieval gallego (1350-1450)», Acta historica et archaelogica Medievalia, X, Barcelona, 1989, págs. 427. 432.

17 Sobre esta cuestión, véase CHAFFEE, D.: «Ekphrasis in Juan de Mena and the Marqués de Santillana», Romance Philology, XXXV, 1981-2, págs. 609-16. 
cuitura podría ser una bola dorada ${ }^{18}$. Esta interpretación me parece excesivamente aventurada ya que, ni se conocen paralelos o precedentes para una composición semejante, ni el término "vulto» puede ser entendido como «bola». El Tesoro de la Lengua Castellana o el Diccionario de Autoridades, registran para esta palabra acepciones como las de «imagen», "efigie» o «forma» ${ }^{19}$. Quizás, Mena simplemente se refiera con ello a un pedestal o estrado sobre el que se situaría la escultura.

Además de dejar testimonio de la apariencia del sepulcro, Hernán Núñez fecha con seguridad su destrucción en 1441, año en el que el Infante Enrique se apoderó de la ciudad de Toledo, desafiando a Juan II y su «valido». Curiosamente, las fuentes cronísticas aluden a este hecho pero en ningún momento se menciona la destrucción del monumento ${ }^{20}$, ni siquiera en la del propio Condestable ${ }^{21}$. No obstante, existen dos referencias cercanas en el tiempo que sí corroboran esta versión de los hechos. En los Anales de Garci-Sánchez, jurado de Sevilla, fechados en 1469, podemos encontrar esta breve nota: “En este mes de marzo de 1441 mandó el ynfante don Henrique deshacer en Toledo el bulto del Condestable, que avía

18 Martínez de Aguirre, J.: «La primera escultura gótica en Sevilla: la Capilla Real y el sepulcro de Guzmán el Bueno (1238-1320), Archivo Español de Arte, 270, 1995, págs. 111-129, esp. 120.

19 «Bulto: $\mathrm{s}$. m. Todo aquello que hace cuerpo y abulta y no se distingue lo que es, ò por estar cubierto por alguna cosa, ò por estar muy distante. Algunos son de sentir que esta palabra se debe escribir con v. esto es Vulto por decir que viene del latino Vultus; pero como esta voz en Latín significa sólo el rostro, la cara o el semblante del hombre: por esta razón y la de traher la palabra Bulto con $b$ los Autores más clásicos y Diccionarios, se pone en este lugar». Diccionario de autoridades (ed. facsímil), Madrid, Gredos, 1990, [1726], t. I, pág. 714. A su vez, Covarrubias da una definición todavía más ajustada: «Bulto: 6. Abultar, hacer bulto y cuerpo. Dijose bulto cuasi voluto, voltato, a volvendo, por ser cosa envuelta y confusa, o del nombre latino vultus, que vale cara, rostro, haz, gesto, presencia, talle y de allí bulto, aquello que se nos representa delante. 7. Bulto significa algunas veces la efigie puesta sobre la sepultura de algún príncipe y algunas veces la mesma tumba cubierta. 8. Figura de bulto, la que hace el entallador o o el escultor, por ser figura con cuerpo, a diferencia de de la pintura que es en plano, y con las sombras y claros saca las figuras a que parezcan tener cuerpo y se puedan asir con la mano". SEBASTIÁN DE COVARRUBias, Tesoro de la Lengua Castellana o española, Madrid, Castalia, 1994, [1611], págs. 214-215.

${ }_{20}$ Crónica de Juan II (ed. de C. RosseL), B.A.E., t. LXVIII, Madrid, 1953, [1873], pág. 270. Véase también [Gonzalo Chacón]: Crónica de Don Álvaro de Luna (ed. J. de Mata CaRRIAZO), Madrid, Espasa-Calpe, 1940, cap. XLVIII. Resulta extraña esta omisión, teniendo en cuenta la atención prestada en ellas, especialmente en la Crónica del Halconero, a todo lo que tiene que véase con lo insólito y novelesco de las puestas en escena de la parafernalia caballeresca. véase ANDRÉs DIAZ, R. DE: "Las fiestas de caballería en la Castilia de los Trastámara», En la España Medieval, t. V, 1986, págs. 81-87; Rico, F.: "Unas coplas de Jorge Manrique y las fiestas de Valladolid en 1428", Anuario de Estudios Medievales, II, 1965, págs. 515-524; Ruíz, T.: «Fiestas, torneos y símbolos de realeza en la Castilla del siglo XV» en Realidad e imágenes de poder, Valladolid, 1988, págs. 249-265; PALOMO Fernández, G. y SENRA GABRIEL Y GALÁN, J. L.: "La ciudad y la fiesta en la historiografía castellana», Hispania, LIV/1, 1994, págs. 5-36.

${ }_{21}$ En la Crónica de Don Álvaro de Luna, escrita escrita varios años después de la muerte del Condestable y en pleno proceso de rehabilitación de su figura, se describe brevemente la magnificencia de la Capilla de Santiago, pero no se rastrea ni la más mínima alusión al sepulcro. Al Maestre se le reconoce el mérito de haber "... edificado en la sancta iglesia della [Toledo] la más notable, rica e maravillosa capilla e enterramiento suyo que en las Españas, $e$ aun en la mayor parte del mundo, se pudiese hallar...". [GonZAlo ChaCóN]: Op. cit, cap. CXXVIII, pág. 444. 
Fartan sus iras en forma semblante: La tumba de Álvaro de Luna y el'status...

hecho para su fin, y mandó de ello hacer dos lombardas» 22, misma información que repite la Compendiosa Historia Hispanica de Rodrigo Sánchez de Arévalo (ca. $1470)^{23}$. A partir del siglo XVI, muertos ya todos aquellos que pudiesen haber sido testigos de la colocación del monumento y su destrucción, los versos de Mena y los comentarios de Hernán Núñez serán las referencias que tomen como base todas las recreaciones posteriores del sepulcro. Si examinamos las restantes fuentes textuales conservadas, la mayoría de ellas descripciones de la ciudad de Toledo y su catedral enmarcadas entre los siglos XVI y XIX, comprobaremos que se limitan a reproducir los versos de Mena, añadiendo progresivamente otros datos cada vez más insólitos cuyo origen, como veremos, no resulta fácil de precisar.

En 1549, el Dr. Blas Ortiz, canónigo de renombre dentro de la Catedral toledana, escribe su Descripcion Graphica y Elegantissima de la S. Iglesia de Toledo, encargada por Felipe II, entonces todavía príncipe. El objetivo de esta magna obra era ofrecer al regente una completa visión del edificio catedralicio, con sustanciosos comentarios acerca de su arquitectura e historia que pudiesen satisfacer la curiosidad de un lector cultivado e interesado en estos aspectos, como era el príncipe ${ }^{24}$. El capítulo 28 está dedicado a la Capilla de Santiago, y en él podemos leer: «Empezola a fabricar de arte y estructura elegante antiguamente en tiempo de su prosperidad Álvaro de Luna * mastre de Santiago y condestable de Castilla, y hizo para sí un monumento de bronce, al qual fixó su estatua de la misma materia. Deshiciéronse por mandado del ynfante don Enrique, hijo tercero del rey don Fernando de Aragón que aborrecía grandemente al Condestable. (...) Del monumento y estatua se hizo la pila del sagrado baptismo de esta Sacrosanta Yglesia; o dos bombardas, como se dice en las corónicas [sic] de España que cita el comentador de Juan de Mena, insigne poeta de nuestra lengua, en el metro 264 y 265 • en los cuales se haze mención de él. No obstante, algunos, y acaso más verdaderamente aseveran que se hizo la dicha pila de baptismo y el púlpito donde se predican los sermones al pueblo. El dicho don Álvaro de Luna, aviéndole asaltado su infausta y acerba muerte, dexó acabada esta capilla, pero sin dexarla señalada renta» ${ }^{25}$. Es precisamente este testimonio, nunca citado en relación a la tumba de Don Álvaro, el que podemos considerar como más fiable de cuantos tenemos a nuestra disposición, ya que se encuentra recogido en una obra sancio-

${ }_{22}$ MAta Carriazo, J. de: «Los Anales de Garci-Sánchez, jurado de Sevilla», Anales de la Universidad Hispalense. Filosofía y Letras, XIV, 1953, pág. 30.

${ }_{23}$ Citado en Lenaghan, P.: Op. cit., pág. 137.

24 Véase PEREDA, F.: "Leer en la Catedral: la Experiencia de la Arquitectura en 1549" en La Catedral de Toledo. 1549. Según el Dr. Blas Ortiz (Descripcion Graphica y Elegantissima de la S. Iglesia de Toledo), Toledo, Antonio Pareja Ed., 1999, págs. 84-99.

${ }^{25}$ Gonzálvez, R. y Pereda, F. (eds.): La Catedral de Toledo. 1549. Según el Dr. Blas Ortiz, pág. 215. 
nada por la propia Catedral de Toledo, y encomendada al que, sin duda, era uno de los intelectuales más destacados de su tiempo, humanista de amplia cultura y formación ${ }^{26}$. Hasta el siglo XIX, fue ésta la referencia docta inexcusable sobre la catedral, y prueba de ello es que en el XVIII, Lorenzana la reimprimiese junto a los escritos de los Padres Toledanos ${ }^{27}$. El que Blas Ortiz no incluya ninguna referencia al carácter articulado de la escultura funeraria del Condestable, en una descripción que, por otro lado, destaca por su minuciosidad, resulta altamente sospechoso. Si el monumento hubiese tenido las características que la posteridad le atribuye, el canónigo toledano no habría silenciado su mención en una compilación en torno a las riquezas y excelencias de la catedral primada. Además, en el caso de que dicho monumento hubiese generado ya en fecha temprana esta clase de leyendas, es difícil concebir que el autor no aludiese a ellas, ni siquiera brevemente, cuando, en cambio, recoge diversas historias sobre la reutilización del bronce original del monumento.

El origen de la tradición legendaria que atribuye un carácter articulado a la efigie del Condestable ha de encontrarse, por el contrario, en las referencias que a dicha capilla hace otro canónigo catedralicio, Pedro de Alcocer, en su Hystoria o Descripción de la Imperial cibdad de Toledo, publicada en 1605. En el folio LXXIX vo, comenta los hechos más destacados del reinado de Juan II, con especial atención a la destrucción del sepulcro, de la que acusa a la descontenta población toledana, rebelada contra Don Álvaro en $1449^{28}$ : «... y con poco acatamiento, y reuerencia de tan santo lugar, quebraron dos bultos ricos, y sumptuosos que estaban en la capilla de Santiago, encima de las sepulturas dec dicho Maestre y Condestable don Aluaro de Luna, y de su muger, que el en su vida hizo hazer de laton dorado, de muy rica y subtil obra, hechos por tal arte que los podian hacer leuantar, y poner de rodillas cada vez $\bar{q}$ querian: $y$ del metal $\bar{q}$ dellos sacarō se hizo el vno de los pulpitos antiguos desta iglesia, y la pila de baptizar $\bar{q}$ oy es»29. A continuación, reproduce los comentarios de Hernán Núñezsobre la mega de Valladolid y su profecía $^{30}$. De dónde haya podido tomar Pedro de Alcocer estas noticias, en las que se alude también por vez primera a la efigie de la mujer del Condestable y se atri-

${ }^{26}$ Gonzálvez, R.: «Blas Ortiz y su mundo" en La Catedral de Toledo. 1549. Según el Dr. Blas Ortiz, pág. 11.

27 "La citaron profusamente e imitaron los historiadores toledanos Pedro de Alcocer, Luis Hurtado de Toledo y Francisco de Pisa, para los cuales los términos Historia y Descripción vienen a ser prácticamente sinónimos, por influencia de la tradición clásica". Gonzálvez también apunta que en esta primera guía de la catedral toledana se encuentran referencias precisas que se omiten en otros textos. De la diligencia y constancia de Blas Ortiz da muestras el hecho de que leyese gran cantidad de documentos originales del Archivo Capitular. GonzÁLVEZ, R.: Op. cit., págs. 12-13.

${ }^{28}$ Los hechos se inscriben en la rebelión de Pero Sarmiento.

${ }^{29}$ Véase PEDRo DE AlCOCER, Hystoria o descripción de la Imperial Cibdad de Toledo, Toledo, Juan Ferrar, 1554, f. LXXIXV.

${ }^{30}$ De hecho, todo el pasaje está envuelto en un hábito de fantasmagoría, ya que la propia rebelión se achaca, entre otras cosas, al hallazgo de una misteriosa profecía, de tintes milenaristas. 
Fartan sus iras en forma semblante: La tumba de Álvaro de Luna y el status...

buye a ambas un carácter articulado, es un misterio que no se resolverá nunca con total certeza. Tal vez simplemente esté reproduciendo leyendas orales que corrían en aquel tiempo o sean producto de su imaginación. No obstante, podría tratarse de una contaminación con el recuerdo de otras efigies sedentes medievales, las únicas de esta tipología conservadas entonces: las de Fernando III y Beatriz de Suavia en Sevilla ${ }^{31}$. Ello serviría para explicar tanto la mención de la efigie de la mujer como la alusión al carácter articulado. Cinco década después, Francisco de Pisa repite literalmente esta nueva particularidad de los sepulcros en su Descripción de la Imperial ciudad de Toledo (1617). Sin embargo, incluye sólo los versos de Mena y precisa que, según su comentarista, habría sido el Infante Enrique quien ordenase la destrucción de los monumentos. Curiosamente, en sus notas manuscritas, anteriores a la redacción definitiva de la obra y fechadas hacia 1595, no he podido leer nada relativo al movimiento de las esculturas toledanas. Es posible que entre esta fecha y la de redacción definitiva de la obra el autor hubiese tenido noticia del conjunto sevillano, reconsiderando su idea de no dar crédito a la versión de Alcocer, al que, por otro lado, cita profusamente en el manuscrito y en el texto impreso $^{32}$. Las dudas de Francisco de Pisa no me parecen infundadas. Si la obra de Ortiz era rigurosa en sus afirmaciones, en el texto de Alcocer se detectan, en cambio, errores en la datación de los hechos y datos discordantes que lo desacreditan como fuente documental. El que la leyenda relativa al carácter articulado de las efigies surja casi una centuria después de la destrucción del sepulcro revela el interés de los hombres del XVI por esta clase de ingenios, que el Barroco recuperará en su afán de buscar una respuesta emocional en el espectador, pero también la sugestión que ejercían el enigmático laberitno de fortuna y los relatos nigrománticos de Hernán Núñez. Sea como fuere, todos los historiadores posteriores hasta nuestros días han dado por verdaderas las palabras de este autor, aunque, como vemos, su fiabilidad es más que cuestionable ${ }^{33}$. Sólo Antonio Ponz pasa de puntillas sobre este tema, recordando simplemente que "aún viviendo [Don Álvaro] se mandó hacer para cuando falleciese un sepulcro de bronce dorado, y en él, su estatua de la misma materia, pero que el infante don Enrique, hijo de Fernando, rey de Aragón, que aborrecía en gran manera al condestable, se lo deshizo todo

31 Estas imágenes serían apartadas de su ubicación original en la Capilla Real en 1579. Dicho traslado aparece recogido en ANTONIO MORGADO, Historia de Sevilla en la qual se contienen sus antigüedades, grandezas y cosas memorables en ella acontecidas desde su fundación hasta nuestros tiempos, Sevilla, 1597, reed. en Archivo Hispalense, s. f., pág. 208 y ss. apud MARTínEz DE AguiRRE, J.: Op. cit., pág. 114.

32 Las notas manuscritas de Francisco de Pisa se encuentra custodiadas en la Biblioteca Universitaria de Santiago, Ms. 212, f. 118 r-v. En cuanto al texto impreso, véase Francisco de PISA, Descripción de la Imperial ciudad de Toledo, Toledo, Pedro Rodríguez, 1617, ff. 200-201.

33 Por si fuera poco, puede darse otra vuelta de tuerca en todo este asunto, ya que esta versión preliminar, más fiel a la descripción de Ortiz, menciona la existencia de una estatua ecuestre de Santiago Matamoros en la batalla de Clavijo: «El qual en lo alto del altar mayor puso la figura de santiago en un cauallo blanco, derribando con su espada muchos moros...» (fol. 118r). 
cuando tomó por armas a Toledo contra el rey don Juan" ${ }^{34}$. El erudito cita las consabidas estrofas de Mena, pero se abstiene de mencionar si las estatuas estaban dotadas de movimiento. No puede extrañarnos este silencio: para un ilustrado, poco crédito o interés podían ofrecer esta clase de artefactos mecánicos, alejados de todo lo que se concebia como «Bellas Artes».

A lo largo del siglo xIx, la tumba de Álvaro de Luna parece convertirse en lugar común para la exaltación de un medievo a medio camino entre el ensueño pintoresco y el "castellanismo" más rancio. Las descripciones inciden en los aspectos artificiosos del sepulcro, proyectando en las palabras de Mena toda una sensibilidad "neogótica" moldeada por los académicos cuadros de historia o la literatura romántica, que tiene en la Edad Media una fecunda inspiración. Más de trescientos años después de su muerte, la discusión sobre el ejercicio tiránico del poder por parte del Condestable deja paso a la más denodada defensa de su figura como exponente de las virtudes del caballero castellano, incluso en su hora postrera. Como ejemplo de ello, sólo hay que recordar los Romances históricos del Duque de Rivas. Buena prueba de esta actitud hacia el pasado son las descripciones y guías eruditas que se escriben sobre la ciudad de Toledo o su catedral, en las que siempre hay un hueco para la semblanza de la Capilla de Santiago y su asombroso sepulcro broncíneo.

La obra mejor documentada de las que se escriben en este momento es el Toledo en la mano, de Sixto Ramón Parro. Cautivado por el personaje, el investigador decimonúnico precisa que el sepulcro «según describen los autores contemporáneos era todo de bronce y tenía echada encima la estatua del Condestable, pero de tal modo construida que tocando un resorte se levantaba y arrodillaba cuando decían misa, volviéndose a tender luego que acababan de celebrar... ${ }^{35}$. Asimismo, menciona las dos hipótesis en torno a su destrucción y, como de costumbre, cita las coplas del poeta. No obstante, conviene destacar los matices que introduce a la hora de describir el sepulcro: ahora la estatua no está sentada, sino echada y lo que es más interesante, está provista de un mecanismo que permite su funcionamiento autónomo. Es más, Parro recoge otra versión sobre el fin de tan pasmoso artefacto, ya que según ciertas fuentes, la reina Isabel habría retirarado los sepulcros «para evitar la irreverencia que causaba á los concurrentes á oir misa en ella el movimiento de la estátua al levantarse, arrodillarse y tenderse» ${ }^{36}$. De to-

34 Antonio Ponz, Viaje de España (ed. de C. M. de RIVERo), tomo I, carta II, Madrid, Aguilar, 1988, [1787], págs. 133-135.

35 RAMÓN PARRO, S.: Toledo en la mano, Toledo, Instituto Provincial de Investigaciones y Estudios Toledanos, 1978, [1857], pág. 381.

36 Ibidem, pág. 382. Este dato parece estar tomado de Eugenio Robles, ya que a él alude Amador de los Rios al citar la misma información (véase infra). No he podido localizar la obra ni fecha de edición en la que este autor hace dicha afirmación. En cualquier caso, parece remitir a la obra Historia Episcopal y 
Fartan sus iras en forma semblante: La tumba de Álvaro de Luna y el status...

das formas, considera compatible la nueva version con la de Juan de Mena, proponiendo que las estatuas serían restauradas por Don Álvaro tras su violenta destrucción y no habrían sido fundidas hasta el tiempo de los Reyes Católicos.

Poco es lo que aportan otras obras contemporáneas de la de Parro, como las de Quadrado ${ }^{37}$ o Amador de los Ríos. El insigne historiador se permite fantasear aventurando que se erigía «en mitad de la capilla un magnífico mausoleo de bronce dorado, ornado de estátuas que recibian movimiento por medio de resortes, viéndose en el centro la del condestable, armada de pies a cabeza y asentada sobre un "gran bulto de oro», según la expresión de su coetáneo Juan de Mena» ${ }^{38}$. Esta misma recreación aparece en el estudio de Pedro Blanco y Manuel Assas EI indicador toledano ó guía del viajero en Toledo, publicado en $1851^{39}$. Tendremos que esperar a 1880 para que vea la luz el primer estudio monográfico sobre la tumba, debido al historiador y literato Pedro María Barrera ${ }^{40}$. En él encontramos una completísima y rigurosa compilación de prácticamente todas las fuentes hasta aquí citadas, además de una selección del material documental relacionado con la compra y dotación de la capilla por el Condestable y sus descendientes. No obstante, ni siquiera en época tan avanzada puede el investigador sustraerse a la fascinación que ejerce la tumba todavía, y que genera nuevas leyendas de cuño inequívocamente romántico. De este modo, Barrera da noticia de sendas supuestas incursiones en una cripta situada bajo la capilla. En el curso de la primera de las exploraciones, que tuvo lugar en 1808, se habrían encontrado, según un maestro cantero de la Fábrica, los «esqueletos sentados en sillones antiguos alrededor de una mesa, sobre la cual tenía su calavera delante el que suponían sería el de Don Álvaro" " ${ }^{41}$. Una segunda incursión en la cripta se habría realizado en 1846 , con motivo de la visita de Alexandre Dumas, aunque en esta fecha «no existían en el primero más esqueletos que los de D. Álvaro y de doña Juana, por cierto sentados junto á una mesa, como cuarenta años antes los había visto Forero [el maestro cantero]» ${ }^{42}$. El hecho de que se vincule al escritor francés con esta se-

Real de España del historiador del siglo XVII Baltasar Porreño (Biblioteca Capitular de la Catedral de Toledo, caj. 27, núms. 21-22), en la que se lee: «estos bultos mandó deshacer la Catholica Reina Doña Isabel, después de hauer sido malatratados por el tiempo", tal y como aparece citado en BENITO RUANo, E.: Toledo en el siglo XV, Madrid, CSIC, 1961, pág. 37.

37 Quadrado, J. M.: Toledo y Ciudad Real, Barcelona, El Albir, 1980, [1853], págs. 73-74, 133 y 232-233.

38 AmAdOR DE LOS Ríos, J.: Toledo pintoresco o descripción de sus más celebérrimos monumentos, Barcelona, El Albir, 1976, [1845], pág. 56.

39 Blanco, P. P. y Assas, M.: El indicador toledano, Madrid, Colegio Nacional de Sordomudos, 1851.

40 Barrera, P. M.: «Sepulcro de D. Álvaro de Luna en la capilla de Santiago de la Catedral de Toledow en Museo Español de Antigüedades, t. X, 1880, págs. 255-270.

41 Ibidem, pág. 270. Esta mismo dato aparece recogida en Ramón PARRO, S.: Op. cit., pág. 386 . EI historiador, si hacemos caso a sus palabras, habría escuchado esta noticia de boca del propio protagonista. A su vez, BLANCO, P. P. y Assas, M.: Op. cit., pág. 50, consignan que "en la bóveda subterránea se consignan los restos de ambos esposos".

42 BarRera, P. M.: Op. cit., pág. 270. Curiosamente, él es el único que recuerda tan renombrada visita. 
gunda inspección no puede ser más revelador: ciertamente tan misteriosa cámara, con unos esqueletos sacados de una novela "gótica», podría haber surgido de la mente fabuladora del autor de El conde de Montecristo. Barrera, queriendo comprobar la veracidad de estos testimonios efectuaría una última visita a la cripta en 1878. Sin embargo, y como por arte de magia, ya "no encontraron huella ninguna de los mencionados $" 43$. Como podemos comprobar, al igual que los relatos sobre este enterramiento subterráneo, las reconstrucciones decimonónicas de la tumba parecen haber tenido que ver mucho más con la literatura fantástica que con la realidad histórica.

A partir de esta fecha, los escasos trabajos consagrados al análisis de este peculiar monumento se reducen a una serie de alusiones integradas en estudios generales sobre la capilla o los sepulcros actuales ${ }^{44}$. Sorprende comprobar que en casi todos los casos, junto a los consabidos versos de Mena, aparece siempre el mismo aparato documental: una serie de breves frases entresacadas de algunas obras a las que aquí hemos hecho mención. La razón que explica esta coincidencia es que estas citas aparecen reunidas en la obra Toledo en el siglo XV del gran historiador Eloy Benito Ruano ${ }^{45}$. Tal y como hemos comprobado en el análisis diacrónico de las fuentes, las aseveraciones de Pedro de Alcocer descansan en una base tan débil que no es posible considerarlas como fiables. Sin embargo, todos los autores mencionados las recogen como veraces $\sin$ demasiadas reticencias, y lo que es más, algunos se dejan llevar por la ensoñación de los eruditos decimonónicos y llegan a considerar la posibilidad de que fuesen no sólo figuras articuladas sino autómatas ${ }^{46}$. Pero tras este largo recorrido a través de la progresiva fabulación en torno al sepulcro del Condestable, llegamos a la conclusión de que únicamente pueden considerarse seguros los testimonios sobre su apariencia original que nos proporcionan Juan de Mena y su comentarista.

43 Ibidem, pág. 270.

44 Además de las obras de Lenaghan y Marínez de Aguirre, ya citada, véanse también GiLMAN Proske, B.: Castilian Sculpture: Gothic to Renaissance, New York, Hispanic Society of America, 1951, pág. 181; FernánDEZ GonzÁleZ, E.: «Don Álvaro de Luna, Condestable de Castilla y Maestre de Santiago: hombre de su tiempo y promotor de las artes» en La nobleza peninsular en la Edad Media. VI Congreso de Estudios Medievales, León, Fundación Sánchez Albornoz, 1999, págs. 135-170; FRANCo MATA, A.: «El gótico en Toledo» en Arquitectura en Toledo (VV.AA), t. I, Toledo, 1992, págs. 412-458; PÉREZ HiGUERA, T.: «El sepulcro del arzobispo Sancho de Rojas, en su capilla de la catedral de Toledo» en Homenaje al profesor Hernández Perera, Madrid, 1992, págs. 557-583; CortÉs ARRESE, M. A.: El espacio de la muerte y el arte de las órdenes militares, Cuenca, Ediciones de la Universidad de Castilla-La Mancha, 1999, págs. 159-80; Luz LamarcA, R. de: El Marquesado de Villena o el mito de los Manuel, Cuenca, Diputación Provincial, 1994, págs. 216-7; BANGo ToRviso, I. G.: «El espacio para enterramientos privilegiados en la arquitectura medieval española», Anuario del Departamento de Historia y Teoría del Arte (U.A.M.), vol. IV, 1992, págs. 93-132; YARZA LUACES, J.: «La imagen...», págs. 268-269 y 280.

45 Véase la obra ya citada de BENito RuANO, E., Toledo en el siglo XV, págs. 36-37.

46 Así por ejemplo, Fernández González, E.: Op. cit., pág. 151, y sobre todo Martínez de AGUiRRE, J.: Op. cit., pág. 120. Véase también Lenaghan, P.: Op. cit., pág. 136. 
Fartan sus iras en forma semblante: La tumba de Álvaro de Luna y el status...

En efecto, el monumento del Condestable se decoró originalmente con una efigie de cobre sobredorado, que lo representaba sentado y armado. Sobre la existencia del sepulcro de Juana Pimentel y la posibilidad de que ámbos pudiesen estar articulados o dotados de un mecanismo que permitiese su movimiento, nada puede decirse con seguridad. Por otro lado, la propuesta de Sixto Ramón Parro de que los sepulcros hubiesen sido reconstruidos por el Condestable resulta bastante inverosímil. En primer lugar, porque no existe constancia de que el de Juana Pimentel se hubiera llegado a colocar allí a mediados del $x v^{47}$; y en segundo lugar porque los recursos de Don Álvaro en los últimos diez años de su vida distaron mucho de los esplendores de su época de dominio absoluto ${ }^{48}$. Es más, si realmente los hubiese restaurado, no tendría mucho sentido que su hija encargase unos nuevos mausoleos tan sólo treinta años después ${ }^{49}$.

El sepulcro de bronce de Juana Pimentel y el carácter articulado de ambas efigies son, sin duda, fruto de la legendaria imaginación de escritores de los siglos $\mathrm{XVIII} \mathrm{y} \mathrm{XIX,} \mathrm{que} \mathrm{debieron} \mathrm{encontrar} \mathrm{escasamente} \mathrm{sorprendente} \mathrm{el} \mathrm{conjunto} \mathrm{tal} \mathrm{y}$ como los describían los autores contemporáneos de su creación. No alcanzaban a comprender que en la época en que el Condestable ordenó su tumba, la efigie sedente en un contexto funerario constituía no sólo una excepción tipológica, sino in-

${ }^{47}$ Varios testimonios aseguran que el Maestre no puedo véase terminada su capilla, 0 al menos, no llegó a dotarla. Recordemos que Blas de Ortiz señalaba que el Condestable «dexó acabada esta capilla pero sin dexarla señalada renta". Por su parte, Francisco de Pisa afirma en la versión preliminar de su obra que "don Alvaro de Luna, "atajado" con la muerte desasistida e infeliz, dexo imperfecta la obra desta capilla y sin dotación" (Biblioteca Universitaria de Santiago, Ms. 212, f. 118v). El proceso constructivo de la capilla ha sido trazado por Ángela Franco y Etelvina Fernández, basándose en un estudio riguroso de la documentación conservada. Parece que tras la llegada de Hannequin de Bruselas, entre 1443-1445, éste se haría cargo de las obras, aunque es probable que la capilla no fuese finalmente dotada hasta 1484. Véanse también GonZÁLEZ PALENCIA, C.: «La capilla de don Álvaro de Luna en la catedral de Toledo", Archivo Español de Arte y Arqueología, 13, 1929, págs. 109-22; AzCÁRATE, J. M. de: «El maestro Hannequin de Bruselas», Archivo Español de Arte, t. XXI, 1948, págs. 117-182; Idem: «Alvar Martínez, maestro de obras de la catedral de Toledo", Archivo Español de Arte, 1950, págs. 1-12; KonRADESHE:M, C.: «Hanequín Coeman de Bruxelles, introducteur de l'art flamand du XVème siècle dans la région Toledane», Mélanges de la Casa de Velázquez, t. XII, 1976, págs. 126-140.

${ }_{48}$ Según las conclusiones a las que llega Nicholas Round en su brillante estudio, incluso tras la batalla de Olmedo (1445), en la que venció definitivamente a los Infantes de Aragón y sus partidarios, la situación del Condestable no fue todo lo favorable que podría parecer. Lejos de su momento de apogeo en la década entre 1431-1441, Don Álvaro ya no volvió a gozar del control absoluto y unipersonal de todos los resortes del gobierno. Sus ingresos disminuyeron notablemente, viéndose obligado a utilizar todos sus recursos de hábil político para mantener su situación de privanza en el panorama de un reino castellano que comenzaba a írsele de las manos. Round, N.: The greatest man uncrowned. A study of the fall of Don Álvaro de Luna, Londres, Tamesis Books Limited, 1986, págs. 34-35.

49 No hace falta decir que estos mausoleos están fechados en 1489 con plenas garantías, y que la idea de que los antiguos sepulcros hubiesen sido retirados por orden de la reina Isabel carece de todo fundamento. 
cliso una desvergonzada ostentación de poder terrenal en un personaje de dudosa cuna y acelerada ascensión política ${ }^{50}$.

Al final, paradójicamente ha sido su destrucción la que ha asegurado al sepulcro el cumplimiento de la misión memorial, dando cuenta hasta hoy de los hechos de Álvaro de Luna, envueltos en la leyenda como el propio monumento funerario. Si Juan de Mena no lo hubiese escogido como motivo de inspiración, tal vez hoy no estariamos hablando de él. Para ilustrar la consciencia que los castellanos del siglo $\mathrm{XV}$ tenían del poder de los poetas para conferir eternidad a aquellos que escogían como personajes, sólo es preciso recordar un pasaje de El Victorial (1431-46), en el que se reproduce un diálogo imaginario entre César y Virgilio:

«-Virgilio, yo soy despagado mucho de dos cosas que en el mundo veo. Que los nombres de aquellos que grandes hechos hicieron en el mundo, como ellos mueren, mueren sus nombres. Otrosí, que las sus sepulturas son deshechas por luengos tiempos y no duran. $Y$ pues ál no queda del hombre en este mundo después que muere, estas dos cosas quería que fincasen de mi, el nombre y la sepultura; que durasen siempre en cuanto gente hubiese.

Dijo Virgilio:

-Yo haré que el tu nombre y la tu sepultura duren en el mundo» 51.

\section{LA DESTRUCCIÓN DEL SEPULCRO DE DON ÁLVARO $Y$ LAS «HUMILLACIONES» RITUALES DE LAS IMÁGENES}

El rastreo exhaustivo de las fuentes escritas relativas al célebre sepulcro de Don Álvaro de Luna desmiente, pues, la tradición legendaria que describía la efigie funeraria del Condestable como una imagen articulada. Este supuesto carácter articulado ha llevado a algunos autores a integrar el desaparecido conjunto en una tradición cuyo precedente más sorprendente y notable se encontraría en las tumbas reales sevillanas, es decir, en las imágenes articuladas y sedentes de Fernando III, Beatriz de Suavia y Alfonso X, que se hallaban en la Capilla Real de la catedral andaluza ${ }^{52}$. Como hemos visto, conviene calibrar de nuevo la relación entre

50 Esta interpretacion de la destrucción se encuentra ya en la Compendiosa Historia Hispánica de Rodrigo Sánchez de Arévalo, quien condenaba el hecho de que un bastardo construyese una tumba ostentosa en un lugar en el que los reyes de Castilla habían escogido para sí mortajas tan humildes. Citada en Lenaghan, P.: Op. cit., pág. 137.

51 Gutierre Díez de Games: El Victorial. Crónica de don Pero Niño, conde de Buelna (ed. de Jorge Sanz), Madrid, Ed. Polifemo, 1989, pág. 30.

52 Martínez Aguirre es el primer investigador que ha puesto en conexión estas tres obras. MARTíNEZ DE AguiRre, J.: Op. cit., pág. 120. Por su parte, Etelvina Fernández recoge en su artículo la existencia de estos precedentes, aunque sin establecer una relación directa. Véase FERNÁNDEZ GonzÁLEZ, E.: Op. cit., pág. 151. Además de estos artículos, ya citados, en relación a las tumbas sevillanas véase SÁNCHEZ AMEIJEIRAS, R.: "La fortuna sevillana del Códice Florentino de las Cantigas: tumbas, textos e imágenes", Quintana, I, 2002, págs. 257-73. También se encuentran referencias a estos monumentos en YARZA LUACES, J.: 
estos dos conjuntos hoy desaparecidos: resulta muy plausible que el ambiente que rodeó al traslado de los monumentos sevillanos en 1579 afianzase la leyenda del carácter articulado de la efigie toledana, a la que habría de contribuír también el tono de escenografía novelesca que envuelve otras empresas artísticas del Maestre, como las «invenciones» ideadas en su castillo de Escalona ${ }^{53}$.

Pero, ante todo, es el ensañamiento con que fue destruida lo que puede considerarse como desencadenante de esta tradición legendaria en torno a la tumba. Precisamente, este hecho invita a la reflexión en torno al estatuto de las imágenes y, más en concreto, de las efigies de personajes vivos, en la Castilla tardomedieval. Sin duda, las imágenes conmemorativas de entonces respondían a un deseo de perpetuación. Curiosamente, el propio Condestable proporciona en sus escritos un testimonio acerca de su función memorial. Al referirse a las honras fúnebres tributadas a Clelia por los romanos en su Libro de las Virtuosas e Claras Mujeres, explica cómo pusieron «... su ymagen en lo más alto de la carrera por donde todos pasauan, por que su memoria quedase para siempre, e tanta grandeza de coraçon non fuese escondida a los que despues della viniesen, e otros tomasen exiemplo de cometer e fazer por el bien público cosas e fechos señalados e virtuosos» ${ }^{54}$. Si las imágenes se crean para perpetuar la memoria del efigiado, se nos plantea el interrogante de si su destrucción se puede considerar un ejemplo de damnatio memoriae o se remite a posturas más viscerales e inconscientes, conectadas con la «magia de la imagen» 55 . Dejándonos guiar, una vez más, por Laberinto de Fortuna nos encontramos con una toda una formulación en endecasílabos de esta cuestión. En la copla CCLXVI, la siguiente a aquella en la que se describe la destrucción de la tumba, leemos que:

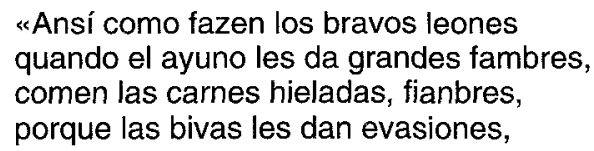

"Ansí como fazen los bravos leones quando el ayuno les da grandes fambres, comen las carnes hieladas, fianbres, porque las bivas les dan evasiones,

\footnotetext{
«Despesas fazen los hombres de muchas guisas en soterrar los muertos", Fragmentos, 2, 1985, págs. 4-19, esp. 7-8; y SANZ, M. J.: «Imagen del antiguo tabernánculo de plata, de la Capilla Real de Sevilla, a través de sellos medievales", Laboratorio de arte, 11, 1998, págs. 51-67.

${ }^{53}$ En la Crónica de Álvaro de Luna se le describe como «mucho dado a fallar invenciones, e sacar entremeses en fiestas o en justas, o en la guerra; en las cuales invenciones muy agudamente significaba lo que queria". Citado en STERN, $\mathrm{CH}_{\text {H.: }}$ The Medieval Theater in Castile, Birmingham-New York, Medieval Renaissance Texts \& Studies, 1996, pág. 100. Véase además bibliografía citada en la nota 18.

${ }^{54}$ P. 87 ab. Citado en LIDA DE MALKIEL, M. ${ }^{\text {R }}$.: La ldea de la Fama en la Edad Media Casiellana, Madrid, FCE, 1983, [1952], pág. 253.

${ }_{55}$ El punto de partida inexcusable en relación a estas cuestiones sigue siendo la obra de FREEDBERG, D.: El poder de las imágenes, Madrid, Cátedra, 1989, esp. págs. 107-26, 229-358. Se incluyen abundantes testimonios sobre imágenes "dotadas de vida", sobre la respuesta que esto genera en el espectador, así como en relación a destrucciones y castigos rituales operados a través de imágenes. Véase también FLYNN, T.: El cuerpo humano en la escultura, Madrid, Akal, 2002, págs. 8-11. Por su parte, Jean Wirth también realiza interesantes precisiones en torno al estatuto de las imágenes y a la progresiva desaparición del ius imaginum en la Edad Media. WIRTH, J.: L'image médiévale. Naissance et développements (Vk-XV' siècles), Paris, Méridiens Klinsieck, 1989, esp. pág. 105.
} 
bien asi fazen las costelaçiones

quando a sus fados fallan un obstante:

fartan sus iras en forma semblante

donde exsecutan sus inpresiones" 56 .

Mena expone con su carga retórica habitual un interesante ejemplo de magia simpática asociada a las imágenes ${ }^{57}$. Sin embargo, con gran ironía, el propio Don Álvaro respondió al Infante Enrique en unos versos que dan cuenta de su actitud respecto a estas creencias supersticiosas:
"Si flota vos combatió, en verdad, Señor Infante, mi bulto non vos prendió quando fueste mareante, para que hiciésedes nada a una semblante figura que estaba en mi sepultura para mi fin ordenada» 58 .

En ellos, el Condestable se refiere a la derrota de la flota aragonesa en Ponza (1435), recordándole que su escultura funeraria no ejerció ningún poder sobre los hados, para merecer tal castigo. Sin embargo, tras la caída en desgracia y muerte de Don Álvaro, los castellanos de finales del siglo xv parecen haber dado por hecho la existencia de algún tipo de magia en estos hechos, a juzgar por el comentario de Hernán Núñez al episodio de la maga de Valladolid, a la que antes he aludido: "Estando en la villa de Llerena oy dezir a vn hombre anciano y digno de creer que los de la valía del condestable se aconsejauan con una maga que estaua en Valladolid, y los que seguían el partido de los infantes se aconsejauan con vn religioso, freyle de la Mejorada, que es un monasterio cabe la villa de Olmedo, el cual grand nigromántico y asy mismo como don Enrrique de Villena; qu'el condesta[ble] auía de ser fecho pieças, lo cual salió verdad quando lo degollaron». Al referirse a un verso de la copla siguiente, en el que el poeta afirma que tras este castigo ejecutado sobre su efigie la Fortuna será favorable al Condestable, Núñez no puede evitar recordar que «mal profeta fue enesto el autor» 59 .

Precisar cuál pudo ser la intención del Infante al ordenar la destrucción de estatua, no deja de ser un ejercicio de especulación. Su rivalidad con Don Álvaro fue llevada al terreno personal, y el hecho de que por tres veces se desafiasen en duelo a muerte, da

\footnotetext{
56 Laberinto de Fortuna, copla CCLXVI, ed. cit., pág. 174.

57 La creencia en la "magia simpática", tal y como explican Freedberg y Flynn, supone la anulación por parte del espectador de la distancia entre imagen y prototipo, y el convencimiento de que realmente existe una relación causa-efecto entre las acciones realizadas con respecto a la imagen y lo que le ocurra al efigiado.

${ }^{58}$ Citado por Hernán Núñez.

${ }^{59}$ Citado en la edición de Kerkhof, págs. 238-239.
} 
Fartan sus iras en forma semblante: La tumba de Álvaro de Luna y el status...

cuenta de lo encarnizado y obsesivo de su enfrentamiento ${ }^{60}$. Tal vez, el que estos duelos no llegasen a tener lugar le impulsó a destruír figurativamente a su adversario, en un intento por mutilar simbólicamente la memoria de su fama, eliminando un soberbio mausoleo que entablaba directa competencia con las Capillas de Reyes Viejos y Reyes Nuevos ${ }^{61}$. Ningún testimonio nos demuestra que el Infante atribuyese algún sentido propiciatorio a esta acción. Pero resulta inevitable establecer una relación entre este episodio y los ceremoniales de degradación (deshonoirement) codificados por la caballería desde el siglo XIV. El capturador ordenaba que las armas del prisionero rebelde fueran exhibidas invertidas en lugares públicos, o si no un retrato suyo, armado, colgando del revés o en otra posición degradante ${ }^{62}$. Una ceremonia de este tipo tuvo lugar en 1431 , en la iglesia del priorato santiaguista de Uclés, y en ella el propio Infante fue protagonista, a su pesar. Según se describe en la Crónica del Halconero y en la refundición que de la misma realizó Lope de Barrientos, los partidarios de Álvaro de Luna, administrador de la Orden de Santiago, se reunieron para llevar a cabo la deposición «en efigie» del Maestre, el Infante Enrique de Aragón ${ }^{63}$. Éste, por supuesto, no estaba presente, y siguió ostentando oficialmente su cargo hasta su muerte en la batalla de Olmedo (1445). Tras el fallecimiento del rival, el papado sancionó lo que era una realidad desde hacía más de diez años, y Álvaro de Luna pasó a ser el único Maestre de la Orden.

Tanto la Crónica del Halconero como su refundición, insisten en el hecho de que para desposeer al infante de su cargo se utilizó una «estatua», monigote de madera o paja, que sentaron en la silla del Maestre revestida con todos los emblemas de su poder: la capa, el birrete, la espada, el sello y el pendón de la Orden. A lo largo del ritual, que es definido como auto, distintos comendadores santiaguistas fueron arrancando cada una de estas insignias al monigote, para, finalmente, derribarlo del asiento.

Tenemos noticia de otro ejemplo de «humillación» de imágenes en el siglo xV castellano: el episodio conocido como Farsa de Ávila, "extraordinaria ceremonia constitucional y ritual» por la que el 5 de junio de 1465 el rey Enrique IV fue destituido en efigie. Al igual que había sucedido en la deposición ritual de Uclés, algunos grandes, como el cardenal Carrillo o el Marqués de Villena, fueron arrebatando todas sus insignias (trono, corona, cetro y espada) a un muñeco que representaba al monarca ${ }^{64}$.

60 Benito Ruano, E.: Los infantes de Aragón (Monografías de ciencia moderna), 34, Madrid, CSIC, 1952, págs. 96-97. Dos de estos desafíos se lanzaron entre 1439 y 1440, muy cerca por tanto, de los hechos aquí comentados.

61 LeNAGHAN, P.: Op. cit., págs. 136-137. El investigador norteamericano se refeiere a la carga de "presencia» que podrían tener estas imágenes a ojos de sus contemporáneos.

62 KeEN, M.: La caballería, Barcelona, Ariel, 1986, pág. 232.

63 Véase Pablo CarRillo de Huete: Crónica del Halconero de Juan II (ed. de J. de Mata Carriazo), Madrid, Espasa, 1953, cap. LXX, págs. 86-87. LOPE DE BARRIENTOS, Refundición de la Crónica del Halconero (ed. de J. de MATA CARRIAZO), Madrid, 1946, cap. LX, págs. 111-113.

64 Sobre esta cuestión, véase el iluminador estudio de MacKay, A.: «Ritual and propaganda in fifiteenth-century Castile», Past and Present, 107, 1983, págs. 3-43. La ceremonia de Uclés reafirma a 
Tanto el castigo de Uclés como la Farsa fueron actos de dimensión pública y política ${ }^{65}$. La utilización de imágenes en los dos ceremoniales puede equipararse a la utilización de efigies en los funerales reales ingleses y franceses, ya que en ellos el status de las imágenes responde a lo que entendemos en la actualidad por representación: entre lo representado y el signo utilizado para tal fin existe una distancia conceptual ${ }^{66}$. No obstante, las similitudes entre estos dos fenómenos nada deben a una influencia directa, sino a una evolución en la conceptualización de las instituciones políticas y sociales, que tiene su repercusión en el estatuto jurídico que adquieren sus símbolos ${ }^{67}$.

La destrucción del sepulcro del Condestable no fue, en cambio, un ritual operado a través de una imagen a la que se le reconoce un estatuto jurídico, sino un acto de violencia puntual. Sin embargo, debido a la existencia de rituales de «humillación en efigie» estipulados en instancias reguladas de poder, quizás se trató también de una acción estratégica, cuidadosamente calculada por el Infante, consciente como era de sus posibles valores simbólicos. Por otro lado, en una época en la que la hechicería estaba integrada plenamente en el esquema cultural, incluso entre la élite cultivada, el castigo a la efigie del Condestable pudo ser interpretado además como el desencadenante de su infortunio ${ }^{68}$. Y, en efecto, los comentarios de Hernán Núñez atestiguan que la caída en desgracia del Condestable fue considerada a posteriori, por muchos de sus contemporáneos, como la consecuencia funesta de aquella acción.

\footnotetext{
Mackay en su consideración de los hechos de Ávila como un drama político, en el que la imagen actúa como representación del monarca desposeído. Además se vistió al monigote de luto, como si el monarca hubiese muerto, y se realizaron las manifestaciones habítuales de duelo en estos casos. Por último, se proclamó al Infante Alfonso como sucesor, con el grito tradicional de "iCastilla por el Rey don Alfonso!". Pero lo que nos interesa aquí, es que, como afirma MacKay, "there is no shred of evidence to show thath anyone really belived that the statue became Henry $\mathrm{V}$ ". Parafraseando a Kantorowicz, en la Farsa. "this statue-king had two bodies: the person of the king was already envisaged as dead, but Kingship was still attached to it until all the royal insignia were removed". MACKAY, A.: Op. cit., pág. 11 y 19.

${ }^{65}$ El carácter para-teatral de estas representaciones políticas es destacado en STERN, CH.: Op. cit., págs. 100-102.

${ }_{66}$ Véase el imprescindible estudio de Kantorowicz, E. H.: Los dos cuerpos del rey. Un estudio de teología política medieval, Madrid, Alianza, 1985, [1957], págs. 385-470. Véase también GiESEY, R. E.: Le Roy ne Meurt Jamais. Les obsèques royales dans la France de la Renaissance, Paris, Flammarion, 1987. Interesante, aunque matizable, es el estudio de GINZBURG, C.: "Representación. La palabra, la idea, la cosa", Annales. E.S.C., 1991. Este ensayo ha sido recogido en Ojazos de madera. Nueve ensayos sobre la distancia, Barcelona, Península, 2000, págs. 83-103.

${ }_{67}$ La definición de la dignidad regia en Castilla se fundamenta en razones más prosaicas que en estos dos reinos. Me remito al ya clásico estudio de Ruiz, T.: «Une royauté sans sacre: la monarchie castillane du bas moyen-âge", Annales. E.S.C., 39, 1984, págs. 429-53. Véase también el monumental trabajo de LineHAN, P.: History and the Historians of Medieval Spain, Oxford, Clarendon Press, 1993, págs. 560-613. Para una opinión diametralmente opuesta, véase NiETo SORIA, J. M.: Ceremonias de la realeza. Propaganda y legitimación en la Castilla Trastámara, Madrid, Nerea, 1993.

${ }^{68}$ Como recuerda Round, "the fact that astrology and alchemy, (...) did promise rewards in terms of power and wealth, and did form an accepted, if shady, part of the fifteenth-century cultural scheme, reinforced such suspicions, even when they were quite unfounded». RouND, N.: «Five Magicians...», pág. 805.
} 